\title{
Effect of serum calcium status at calving on survival, health, and performance of postpartum Holstein cows and calves under certified organic management
}

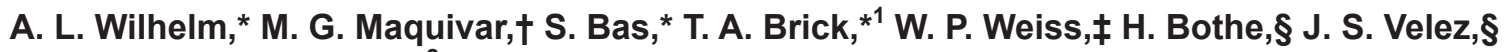 \\ and G. M. Schuenemann ${ }^{* 2}$ \\ *Department of Veterinary Preventive Medicine, The Ohio State University, Columbus 43210 \\ †Department of Animal Sciences, Washington State University, Pullman 96164 \\ ¥Department of Animal Sciences, The Ohio State University, Wooster 44691 \\ §Aurora Organic Farms, Boulder, CO 80302
}

\section{ABSTRACT}

The study objective was to assess the effect of hypocalcemia (HYPO; $\leq 2.0 \mathrm{mmol} / \mathrm{L}$ ) of the dam at calving on survival, health, and performance of lactating dairy cows and their calves under certified organic management. Prepartum dairy cows (primiparous, $\mathrm{n}$ $=445$; multiparous, $\mathrm{n}=328$ ) from 1 dairy herd were monitored (prepartum pen) for imminent signs of parturition (appearance of amniotic sac outside the vulva) until birth. All calves were subject to the same newborn care, colostrum management, and failure of passive transfer assessment (serum total protein $\leq 5.5$ $\mathrm{mg} / \mathrm{dL}$ ). Serum total calcium of cows was determined in samples taken within $2 \mathrm{~h}$ after calving. To define HYPO cows after calving, a cut-point of total serum Ca concentration with optimal sensitivity and specificity to predict metritis or calf diarrhea was established by using the receiver operator characteristic. The effect of HYPO on survival (died or culled within 60 DIM), health status, and pregnancy per artificial insemination (PAI) for first services of lactating cows were analyzed using the GLIMMIX procedure of SAS. Additionally, the effect of HYPO at calving on days in milk (DIM) at first service (DIMFS), milk yield (kg), milk components (percent fat and protein), and somatic cell count were analyzed for the first 3 Dairy Herd Improvement Association (DHIA) tests using the MIXED procedure of SAS (SAS Institute Inc., Cary, NC). The effect of parity (primiparous and multiparous), body condition score at calving, and manure hygiene score at calving were also included in the statistical models. The ef-

Received July 15, 2016.

Accepted December 14, 2016.

${ }^{1}$ Current address: Veterinary Diagnostic and Production Animal Medicine, College of Veterinary Medicine, Iowa State University, Ames, IA 50011.

${ }^{2}$ Corresponding author: schuenemann.5@osu.edu fect of HYPO at calving on calf survival, serum total protein, and diarrhea within $10 \mathrm{~d}$ of age were assessed using GLIMMIX procedure of SAS. The overall prevalence of HYPO was $14.6 \%$ (2.7\% for primiparous and $30.8 \%$ for multiparous cows). Cows experiencing HYPO at calving had greater proportion of metritis (25.1 vs. $14.7 \%$ ) and culling within 60 DIM (15.9 vs. 6.8\%) compared with non-HYPO cows, respectively. For the first 3 DHIA tests, milk yield and components did not differ between HYPO and non-HYPO cows. The DIMFS as well as proportion of cows with dystocia, births of twins, mastitis, and PAI at first service were not different between HYPO and non-HYPO cows. The proportion of stillbirth, weaned calves, and serum total protein did not differ between calves born from HYPO or non-HYPO cows. However, calves born from HYPO cows had greater incidence of diarrhea (49\%) than calves born $(33.3 \%)$ from non-HYPO cows. Findings from the present study showed that HYPO at calving had significant health implications for both dams and calves under certified organic management.

Key words: organic dairy, hypocalcemia, metritis, calf health

\section{INTRODUCTION}

Clinical hypocalcemia, also known as milk fever in postpartum dairy cows, significantly increases the risk for retained fetal membranes, ketosis, metritis, displaced abomasum, and mastitis (Curtis et al., 1983). According to the National Animal Health Monitoring System, the overall incidence of milk fever in US dairy herds is $4.9 \%$ (USDA, 2008). The incidence of clinical hypocalcemia increases with the age of cows, and it was found in $1 \%$ of first-lactation cows and 4, 7, and $10 \%$ of Holstein cows in their second, third, and fourth or greater lactation, respectively (Reinhardt et al., 2011). Similarly, the incidence of subclinical hypocalcemia in 
postpartum cows increases with the age of cows, and it was present in $25 \%$ of first-lactation cows and 41 to $54 \%$ of cows in their second or greater lactations (Reinhardt et al., 2011). Lactating dairy cows experiencing subclinical hypocalcemia had leukocytes with a compromised ability to fight infections, increasing the risk for developing metritis and thus reducing reproductive performance (Kimura et al., 2006; Martinez et al., 2012).

Sparse literature exists on the incidence of clinical or subclinical hypocalcemia of postpartum cows under certified organic management and on the effect of calcium status of dams at calving on survival, health, and performance of calves. Calves born from hypocalcemic cows have been reported to be at greater risk of developing diarrhea and respiratory events during the neonatal period compared with calves born from non-hypocalcemic cows (Planski and Abrashev, 1987). However, information on pre- and postpartum nutrition diets as well as colostrum management and diagnosis of health conditions was not available. Therefore, the objective of the current study was to assess the effect of hypocalcemia (HYPO) of dams at calving on survival, health, and performance of lactating dairy cows and their calves under certified organic management. The hypothesis was that dairy cows experiencing HYPO at calving would have greater proportions of postpartum metritis and culling within 60 DIM. Furthermore, we hypothesized that a greater proportion of calves born from cows with HYPO at calving would have diarrhea compared with calves born from non-HYPO cows.

\section{MATERIALS AND METHODS}

\section{Animals, Feeding, and Facilities}

Briefly, dairy cows and heifers were housed in barns with access to dry-lot (prepartum) free-stall barns (postpartum) with access to dry lot and milked thrice daily at approximately 8-h intervals. Cows were fed twice daily, in the morning and afternoon, with a TMR formulated to meet or exceed dietary nutritional requirements for lactating and dry dairy cows (NRC, 2001). Additionally, all cows had access to pasture (mixture of alfalfa, ryegrass, and orchardgrass, as well as triticale, wheat, and sorghum). The ingredient and nutrient composition of formulated pre- and postpartum diets (DM basis) are provided in Table 1.

At $1 \mathrm{~d}$ of age, female calves were moved to a calfraising facility and were housed individually in calf hutches. The calves were fed $8 \mathrm{~L}$ of pasteurized milk twice daily in the morning $(4 \mathrm{~L})$ and afternoon $(4 \mathrm{~L})$. This study was conducted from May 2013 through Au- gust 2013. The experimental procedures used in this study were reviewed and approved by the Institutional Animal Care Use Committee, The Ohio State University.

\section{Management of Dry Cows, Calving, and Colostrum}

Weekly, a list of cows was obtained based on their calving dates using on-farm computer records (PCDART, Raleigh, NC). Pregnant cows were dried-off 60 $\pm 3 \mathrm{~d}$ before the expected calving date and moved into a far-off dry pen immediately after last milking. All cows were moved to prepartum pens $21 \pm 3 \mathrm{~d}$ before the expected calving date and were closely monitored by on-farm personnel for signs of parturition every 1 h (Schuenemann et al., 2013) and calved within their pen (dry-lot). Calving ease of cows (assistance provided at birth) was recorded using a 4 -point scale $(1=$ no assistance provided; $2=$ light assistance by 1 person without the use of mechanical traction; $3=$ mechanical extraction of the calf with an obstetric calf-puller; and $4=$ severe dystocia, surgery or fetotomy needed; Schuenemann et al., 2011a). Furthermore, calving date and time and stillbirth were recorded. Immediately after calving, all cows had their BCS assessed on a 5 -point scale with 0.25 -unit increments (Ferguson et al., 1994) by the same person from the research team.

Table 1. Ingredients and nutrient composition (\% unless otherwise noted) of pre- and postpartum diets (DM basis)

\begin{tabular}{lcc}
\hline Item & Prepartum & $\begin{array}{c}\text { Early } \\
\text { postpartum }\end{array}$ \\
\hline Ingredient & & \\
Grass hay & 45.12 & 5.51 \\
Wheat straw & - & 0.95 \\
Alfalfa hay & 25.72 & 28.73 \\
Corn silage & 10 & 16.07 \\
Grain mix & 15.93 & 46.14 \\
Mineral mix & 3.19 & 2.49 \\
Nutrient profile & & \\
NE $(\mathrm{Mcal} / \mathrm{kg})$ & 1.30 & 1.62 \\
$\mathrm{CP}$ & 11.78 & 18.8 \\
$\mathrm{NDF}$ & 45.79 & 28.39 \\
$\mathrm{ADF}$ & 30.78 & 21.23 \\
$\mathrm{Starch}$ & 13.79 & 26.69 \\
$\mathrm{Ca}$ & 1.43 & 1.33 \\
$\mathrm{P}$ & 0.34 & 0.39 \\
$\mathrm{Mg}$ & 0.42 & 0.36 \\
$\mathrm{~K}$ & 1.47 & 1.28 \\
$\mathrm{Na}$ & 0.25 & 0.42 \\
$\mathrm{Cl}$ & 1.10 & 0.38 \\
$\mathrm{~S}$ & 0.36 & 0.23 \\
$\mathrm{DCAD}(\mathrm{mEq} / 100 \mathrm{~g} \text { of } \mathrm{DM})^{1}$ & -5.30 & 25.6 \\
\hline
\end{tabular}

${ }^{1}$ Calculated as follows: $\mathrm{DCAD}=(\mathrm{mEq}$ of $\mathrm{Na}+\mathrm{mEq}$ of $\mathrm{K})-(\mathrm{mEq}$ of $\mathrm{S}+\mathrm{mEq}$ of $\mathrm{Cl})$. The water contribution of $\mathrm{Na}(6.72 \mathrm{mg} / \mathrm{kg}), \mathrm{K}(<1$ $\mathrm{mg} / \mathrm{kg}), \mathrm{Cl}(14.5 \mathrm{mg} / \mathrm{kg})$, and $\mathrm{S}(10 \mathrm{mg} / \mathrm{kg})$ was considered for DCAD (Cumberland Valley Analytical Service, Hagerstown, MD). 
The manure hygiene score (MHS) was recorded using a 3-point scale with 1-unit increments recorded at calving: score $1=$ perineum is completely dry and was free from dirt and manure; score $2=$ perineum is slightly $(<10 \%)$ covered with dirt and manure; and score $3=$ perineum is moderately $(>11 \%)$ covered with dirt and manure (Schuenemann et al., 2011b). Stillbirth was defined as a calf born dead or died (normal gestation length) within $24 \mathrm{~h}$ after birth (Schuenemann et al., 2011a). Fresh colostrum was harvested at the maternity within $2 \mathrm{~h}$ after calving, and all calves received $4 \mathrm{~L}$ of optimum quality colostrum (colostrometer; $>50 \mathrm{mg}$ of IgG/dL; Bartier et al., 2015), not necessarily from their dams, within $3 \mathrm{~h}$ after birth. Calcium supplementation (oral boluses or systemic) was not administered to postpartum cows. Two days after colostrum administration, blood samples were collected from jugular venipuncture of female calves to assess failure of passive transfer (total serum protein $\leq 5.5 \mathrm{mg} / \mathrm{dL}$ ).

\section{Assessment of Calcium Status of Dams}

Blood samples $(8 \mathrm{~mL})$ for determination of serum calcium status were collected from cows within $2 \mathrm{~h}$ after parturition by coccygeal venipuncture (BD Vacutainer, Franklin Lakes, NJ). Immediately after collection, blood samples were centrifuged at 2,785 $\times g$ for $20 \mathrm{~min}$ and serum samples were stored at $-20^{\circ} \mathrm{C}$ until assayed for total calcium. Total serum concentration of calcium was determined in duplicates, using a commercially available kit (Calcium Liquicolor No. 0150, Stanbio Laboratory, Boerne, TX) according to the manufacturer's instructions. To define HYPO cows after calving, a cut-point of total serum Ca concentration with optimal sensitivity and specificity to predict metritis or calf diarrhea was established by using the receiver operator characteristic (ROC) curve.

Assuming that cows experiencing HYPO would have increased incidence of metritis by 10 percentage points (e.g., from 14 to $24 \%$ with a standard deviation of $18 \%$ ) compared with non-HYPO cows, 104 cows per group were needed to permit detecting statistical significance with $95 \%$ confidence and $80 \%$ power. Because the incidences of both calf diarrhea and actual HYPO were unknown, additional cows were sampled as a safety factor.

\section{Diagnosis of Health Events, Milk Weights, and Milk Components}

Weekly, a list of cows to screen was obtained based on their calving dates using on-farm computer records (PCDART, Dairy Record Management Systems, Raleigh, NC). Briefly, postpartum cows were screened for retained fetal membranes (RFM), metritis, and mastitis. Retained fetal membranes was defined as a failure to expel the fetal membranes by $24 \mathrm{~h}$ after parturition (LeBlanc et al., 2002). Metritis was defined as a foul-smelling, brown-red, watery vaginal discharge within the first 20 DIM with or without fever $\left(\geq 39.5^{\circ} \mathrm{C}\right.$; Dubuc et al., 2010). Clinical mastitis was defined as an inflammation of the udder with visible changes in milk (presence of clots or blood at forestripping) within 20 DIM. Milk weights, components (percent fat and protein), and SCC for the first 3 postpartum DHIA tests were collected to assess its association with HYPO. Furthermore, the survival of lactating dairy cows (died or were culled within 60 DIM) was assessed by calcium status at calving.

The incidence of diarrhea in female calves was assessed within $10 \mathrm{~d}$ of age. Diarrhea was defined as the presence of fluid or bloody feces (score $2-3 ; 0-3$ scale) and either $>5 \%$ dehydration (score $3 ; 1-3$ scale) or fever $\left(\geq 39.5^{\circ} \mathrm{C}\right)$ within $10 \mathrm{~d}$ of age (Goodell et al., 2012). The first event of diarrhea was considered for the analysis. All calves (male and female) were considered when assessing the association of dam's HYPO status at calving on stillbirth. Only female calves were used in the present study to assess the association of HYPO at calving on serum total protein, diarrhea within 10 $\mathrm{d}$ of age, and the proportion (\%) of weaned calves at approximately $60 \mathrm{~d}$ of age.

\section{Breeding Management}

For all lactating dairy cows, the reported voluntary waiting period was $45 \mathrm{~d}$. The breeding program was based on estrus detection (using tail chalk plus visual observation) twice daily; all animals presenting signs of standing estrous behavior received AI. Animals that did not display estrous behavior or were not pregnant after 5 consecutive AI were turned into the bull pen. Additionally, open cows at the time of pregnancy diagnosis were re-enrolled in the estrus detection program as described previously. All bulls were subjected to the Breeding Soundness Examination once per year and only bulls with a satisfactory score were used. Pregnancy diagnosis was performed at $40 \pm 3 \mathrm{~d}$ post-AI via transrectal palpation. The days in milk at first service (DIMFS) and the proportion of pregnancy per AI (PAI) at first service were assessed for HYPO and non-HYPO cows.

\section{Statistical Analyses}

For this retrospective cohort study, data from individual lactating dairy cows (e.g., parity, dystocia, 
stillbirth, milk weights) were exported from PCDART into an Excel spreadsheet (Microsoft Corp., Redmond, WA).

The effect of cows experiencing HYPO at calving on birth of twins, metritis, mastitis, culling within 60 DIM, and PAI were dichotomized according to definitions and analyzed using the GLIMMIX procedures of SAS (SAS Institute, 2009). The effect of cows experiencing HYPO at calving on DIMFS, milk weights $(\mathrm{kg})$, and components (SCC and percent fat and protein) were analyzed using MIXED procedure of SAS (SAS Institute, 2009). First-order autoregressive, AR(1), covariance structure was used to account for the correlated data structure between the repeated DHIA measurements within animals. The effect of parity (primiparous and multiparous), BCS at calving, and MHS at calving were also included in the statistical models. Additionally, the effect of dam's HYPO status at calving on stillbirth, diarrhea within $10 \mathrm{~d}$ of age, serum total protein, and the proportion of weaned calves were analyzed using the GLIMMIX procedures of SAS (SAS
Institute, 2009). The final model procedures were attained by eliminating nonsignificant variables from the model one at a time, using the Wald statistic backward selection criterion $(P>0.15)$. A $P<0.05$ was considered statistically significant.

\section{RESULTS}

In total, 773 lactating Holstein cows (445 primiparous and 328 multiparous) from 1 certified organic dairy herd were included in the analyses (Table 2). The total serum $\mathrm{Ca}$ value that predicted metritis with the best sensitivity $(65.6 \%)$ and specificity $(55.4 \%)$ was 2.08 $\mathrm{mmol} / \mathrm{L}$. With this threshold value, it was possible to truly predict $65.6 \%$ of the lactating cows with metritis and $55.4 \%$ of the cows that did not develop metritis later in lactation. Furthermore, the total serum Ca value that predicted calf diarrhea with the best sensitivity $(59.6 \%)$ and specificity $(78.8 \%)$ was $2.0 \mathrm{mmol} / \mathrm{L}$. Using a cutoff value for calcium status of dams at calving of $2.08 \mathrm{mmol} / \mathrm{L}$ (metritis) or $2.0 \mathrm{mmol} / \mathrm{L}$ (calf diarrhea)

Table 2. Effect of calcium status at calving on health, survival, and reproductive performance of Holstein dairy cows ${ }^{1}$

\begin{tabular}{|c|c|c|c|}
\hline Item & $\begin{array}{c}\text { HYPO } \\
(\mathrm{n}=113)\end{array}$ & $\begin{array}{c}\text { Non-HYPO } \\
(\mathrm{n}=660)\end{array}$ & $P$-value \\
\hline 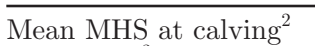 & $1.75 \pm 0.12$ & $1.86 \pm 0.04$ & 0.39 \\
\hline Mean BCS $^{3}$ & $3.56 \pm 0.10$ & $3.47 \pm 0.05$ & 0.37 \\
\hline \multicolumn{4}{|c|}{ Survival and calving-related events (\%) } \\
\hline Dystocia $^{4}$ & 9.1 & 6.5 & 0.52 \\
\hline Birth of twins & 4.4 & 1.7 & 0.26 \\
\hline RFM $^{5}$ & $\begin{array}{r}4.4 \\
12.4\end{array}$ & 5.0 & 0.03 \\
\hline Metritis ${ }^{6}$ & 25.1 & 14.7 & 0.01 \\
\hline Mastitis $^{7}$ & 7.8 & 4.4 & 0.11 \\
\hline Culled within 60 DIM $^{8}$ & 15.9 & 6.8 & 0.01 \\
\hline \multicolumn{4}{|l|}{ Reproductive performance $^{9}$} \\
\hline DIMFS (d) & $82.2 \pm 3.32$ & $79.8 \pm 1.57$ & 0.61 \\
\hline First-service PAI (\%) & 29.4 & 35.9 & 0.21 \\
\hline
\end{tabular}

${ }^{1}$ Least squares means are presented. Blood samples from lactating Holstein dairy cows were collected within 2 $\mathrm{h}$ after calving to assess the calcium status. The proportion (\%) of animals with hypocalcemia (HYPO; $\leq 2.0$ $\mathrm{mmol} / \mathrm{L})$ or non-HYPO $(>2.0 \mathrm{mmol} / \mathrm{L})$ was assessed using total serum calcium concentration.

${ }^{2} \mathrm{MHS}=$ manure hygiene score at calving using 3-point scoring system (Schuenemann et al., 2011b). Least squares means $( \pm$ SEM $)$ are presented.

${ }^{3}$ Body condition score was assessed immediately after calving using a 5-point scoring system with 0.25-unit increments (Ferguson et al., 1994). Least squares means ( \pm SEM) are presented.

${ }^{4}$ Proportion (\%) of cows with dystocia (yes or no); dystocia was defined as a cow with a score of $\geq 2$ at calving using a 4-point scale (Schuenemann et al., 2011a).

${ }^{5}$ Proportion (\%) of cows with retained fetal membranes (RFM; yes or no); RFM was defined as a failure to expel the fetal membranes by $24 \mathrm{~h}$ after parturition (LeBlanc et al., 2002).

${ }^{6}$ Proportion (\%) of cows with metritis (yes or no); metritis was defined as a foul-smelling, brown-red, watery vaginal discharge within the first 20 DIM with or without fever $\left(\geq 39.5^{\circ} \mathrm{C}\right.$; Dubuc et al., 2010$)$.

${ }^{7}$ Proportion (\%) of cows with mastitis (yes or no); mastitis was defined as an inflammation of the udder with visible changes in milk (presence of clots or blood at fore stripping) within 20 DIM.

${ }^{8}$ The proportion (\%) of cows that were culled (sold or died) within 60 DIM was assessed.

${ }^{9}$ Days in milk at first service (DIMFS) and first-service pregnancy per AI (PAI) were based only on estrus detection (using tail chalk plus visual observation) twice daily and all animals presenting signs of standing estrous behavior received AI. Least squares means $( \pm \mathrm{SEM})$ are presented. 
Table 3. Effect of calcium status at calving on milk yield and components (percent fat and protein, and SCC) of Holstein dairy cows for the first 3 DHIA tests relative to calving ${ }^{1}$

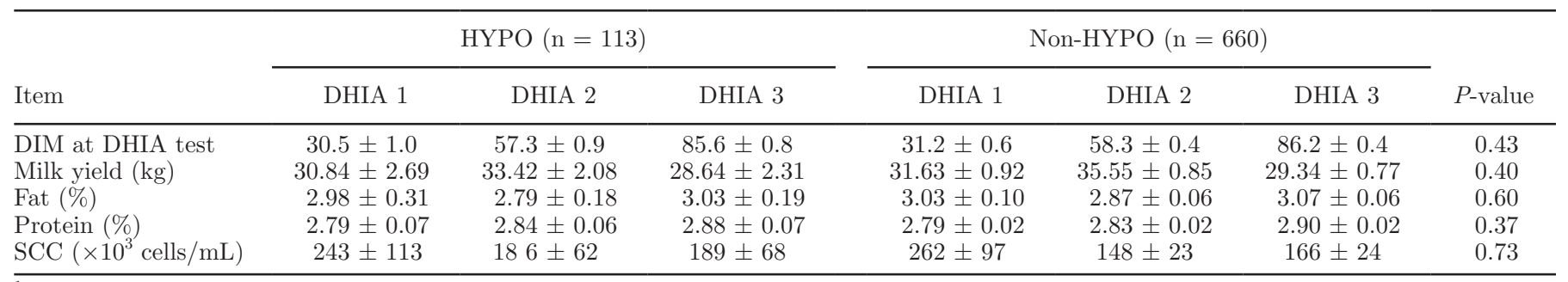

${ }^{1}$ Least squares means are presented $( \pm \mathrm{SEM})$. Blood samples from lactating Holstein dairy cows were collected within $2 \mathrm{~h}$ after calving to assess the calcium status. The proportion (\%) of animals with hypocalcemia (HYPO; $\leq 2.0 \mathrm{mmol} / \mathrm{L})$ or non-HYPO (>2.0 mmol/L) was assessed using total serum calcium concentration.

did not change the statistical significance of variables assessed for both HYPO groups; therefore, HYPO was defined as serum Ca concentration $\leq 2.0 \mathrm{mmol} / \mathrm{L}$ within $2 \mathrm{~h}$ after calving. The overall prevalence of HYPO was $2.7 \%$ for first-lactation cows and $30.8 \%$ for multiparous cows $(21.8 \%$ for second-lactation cows, $33.8 \%$ for thirdlactation cows, and $59.6 \%$ for cows with $\geq 4$ lactations; Figure 1).

\section{Health, Culling, and Performance of Lactating Cows}

The mean MHS $(P=0.39)$ and BCS $(P=0.37)$ of cows at calving did not differ between HYPO and nonHYPO cows (Table 2), regardless of parity group (primiparous vs. multiparous). Lactating dairy cows with HYPO had greater proportion of cows with RFM $(P=$

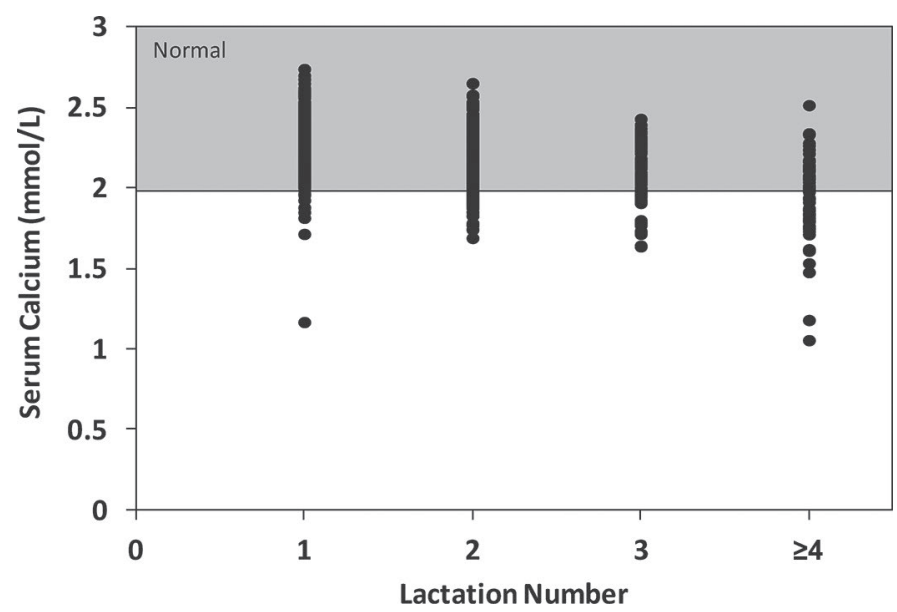

Figure 1. Total serum calcium concentrations of 773 Holstein dairy cows within $2 \mathrm{~h}$ after parturition by lactation number. Blood samples were collected within $2 \mathrm{~h}$ after parturition to assess calcium status by lactation number $1(\mathrm{n}=445), 2(\mathrm{n}=206), 3(\mathrm{n}=65)$, and $\geq 4(\mathrm{n}$ $=57$ ). The overall prevalence of hypocalcemia (HYPO; total serum calcium $\leq 2.0 \mathrm{mmol} / \mathrm{L}$ ) was $2.7 \%$ for primiparous cows and $30.4 \%$ for multiparous cows $21.8 \%$ for second lactation, $33.8 \%$ for third lactation, and $59.6 \%$ for cows with $\geq 4$ lactations).
$0.03)$, metritis $(P=0.01)$, and culling within 60 DIM $(P=0.01$; Table 2$)$. The proportion of cows experiencing dystocia $(P=0.52)$, birth of twins $(P=0.26)$, and mastitis $(P=0.11)$ was not different between HYPO and non-HYPO cows (Table 2). Furthermore, DIMFS $(P=0.61)$ and the PAI at first service $(P=0.21)$ were not different between HYPO and non-HYPO cows (Table 2$)$. Milk yield $(P=0.40)$, percent milk fat $(P=0.40)$, percent milk protein $(P=0.37)$, and SCC $(P=0.73)$ were not different between HYPO and non-HYPO cows for the first 3 DHIA tests relative to calving (Table 3 ).

\section{Calf Survival, Serum Total Protein, and Diarrhea}

The proportion of stillborn calves $(P=0.32)$, serum total protein $(P=0.87)$, and weaned calves $(P=0.41)$ did not differ between HYPO and non-HYPO cows (Table 4). However, calves born from HYPO cows had a significantly greater $(P=0.04)$ incidence of diarrhea compared with non-HYPO cows (Table 4).

\section{DISCUSSION}

Hypocalcemia is a common disorder observed within the first days after calving. It is usually caused by an excessive loss of calcium (colostrum and milk) associated with the up-regulation of calcium absorption by the gastrointestinal tract and inability of the cow to mobilize large quantities of calcium from the bone (Goff, 2008; Reinhardt et al., 2011). In the present study, the overall prevalence of HYPO (clinical and subclinical combined) was $2.7 \%$ for primiparous and $30.8 \%$ for multiparous cows. The incidence of postpartum HYPO (clinical and subclinical) increases with age of the cow, and it is generally higher for cows in their second or greater lactations compared with first-lactation cows (Reinhardt et al., 2011). Ionized calcium is necessary for vital bodily functions such as cellular signaling, 
Table 4. Effect of calcium status at calving on stillbirth, serum total protein, and diarrhea within $10 \mathrm{~d}$ of age and proportion of weaned calves

\begin{tabular}{lccc}
\hline Item $^{1}$ & $\begin{array}{c}\text { HYPO } \\
(\mathrm{n}=113)\end{array}$ & $\begin{array}{c}\text { Non-HYPO } \\
(\mathrm{n}=660)\end{array}$ & $P$-value \\
\hline Stillbirth $^{2}(\%)$ & 2.0 & 2.5 & 0.32 \\
${\text { Serum total protein } \leq 5.5 \mathrm{mg} / \mathrm{dL}^{3}(\%)}_{\text {Diarrhea }^{4}(\%)}^{5}(\%)$ & 49.1 & 2.5 & 0.87 \\
Weaned calves $^{5}(\%)$ & 89 & 92 & 0.04 \\
\hline
\end{tabular}

${ }^{1}$ Least squares means are presented. Blood samples from lactating Holstein dairy cows were collected within 2 $\mathrm{h}$ after calving to assess the calcium status. The proportion (\%) of animals with hypocalcemia (HYPO; $\leq 2.0$ $\mathrm{mmol} / \mathrm{L})$ or non-HYPO $(>2.0 \mathrm{mmol} / \mathrm{L})$ was assessed using total serum calcium concentration. The proportion of stillbirth was assessed for all calves (males and females), but the proportions of serum total protein, diarrhea, and weaned calves were assessed for female calves only.

${ }^{2}$ Proportion (\%) of stillborn calves (yes or no) was assessed. Stillbirth was defined as a calf born dead or one that died within $24 \mathrm{~h}$ after birth, with a normal gestation length.

${ }^{3}$ Proportion (\%) of calves with serum total protein $\leq 5.5 \mathrm{mg} / \mathrm{dL}$ (yes or no) was assessed. Blood samples were collected from female calves $2 \mathrm{~d}$ after colostrum administration to assess the concentration of total serum protein (a calf with $\leq 5.5 \mathrm{mg} / \mathrm{dL}$ was considered as failure of passive transfer).

${ }^{4}$ The proportion (\%) of female calves with diarrhea was assessed within $10 \mathrm{~d}$ of age. Diarrhea was defined as a calf presenting fluid or bloody feces (score $2-3 ; 0-3$ scale) and $>5 \%$ dehydration (score $3 ; 1-3$ scale) or fever $\left(\geq 39.5^{\circ} \mathrm{C}\right)$ within $10 \mathrm{~d}$ of age.

${ }^{5}$ The proportion (\%) of weaned calves was assessed (based on the total of female calves alive $>24 \mathrm{~h}$ ) at $60 \mathrm{~d}$ of age.

muscle contraction, and activation of immune cells among others.

The extracellular calcium status has been shown to be the primary determinant of intracellular calcium status (Kimura et al., 2006). The immunosuppression observed in postpartum dairy cows (Martinez et al., 2012) is likely due to the decreased storage of intracellular ionized calcium; thus, the peripheral blood mononuclear cells have a decreased ability to release a sufficient amount of intracellular ionized calcium for signaling a strong immune response (Kimura et al., 2006). This depletion of intracellular calcium stores likely starts several days before parturition and development of HYPO in early postpartum dairy cows.

In the present study, HYPO cows had a significantly higher proportion of metritis compared with nonHYPO cows. Lactating cows with subclinical HYPO (total serum calcium $\leq 2.14 \mathrm{mmol} / \mathrm{L}$ or $\leq 8.59 \mathrm{mg} /$ $\mathrm{dL}$ ) for at least $1 \mathrm{~d}$ (between 0 and 3 DIM) had fewer neutrophils in their blood with reduced functions and an increased risk for metritis (Martinez et al., 2012). Although DMI was not assessed in the present study, cows experiencing metritis have been shown to have decreased feed intake and reduced eating time before and after calving (Huzzey et al., 2007). Decreased DMI of prepartum cows likely leads to elevated blood nonesterified fatty acids (NEFA) and BHB concentrations, with the subsequent development HYPO and ketosis early in lactation (LeBlanc et al., 2005; Chapinal et al., 2011; Martinez et al., 2012). Additionally, increased concentrations of energy metabolites (NEFA and BHB) within 12 DIM were interrelated with calcium status, thus influencing the risk for postpartum diseases in lactating dairy cows (Martinez et al., 2012). The reduced reproductive performance of HYPO cows is likely due to elevated blood BHB early in lactation and increased risk for metritis (Martinez et al., 2012). In the present study, however, the DIMFS and proportion of PAI for first services were not different between HYPO and non-HYPO cows. Because metritis cases in our study were classified solely based on vaginal discharge (with or without fever at diagnosis) and circulating BHB was not assessed, lactating cows experiencing mild cases of metritis were likely included in the analysis. Perhaps the definition of metritis and the energy status of cows (blood BHB) early in lactation could explain, at least in part, the similar reproductive performance of HYPO and non-HYPO cows in the present study. Another possibility is that a significantly higher proportion of HYPO cows were removed from the herd (culled) before their first AI or pregnancy diagnosis compared with non-HYPO cows. Retrospective studies found that the calcium status of the dam at calving and the early postpartum energy balance increased the risk for diseases and culling (Seifi et al., 2011; Roberts et al., 2012).

Hypocalcemia may compromise DMI postpartum, as reported elsewhere (Jawor et al., 2012; Martinez et al., 2014), which in turn leads to higher blood concentrations of NEFA and BHB (Chapinal et al., 2011; Martinez et al., 2012, 2014). Although HYPO and elevated blood $\mathrm{BHB}$ early postpartum increase the risk for 
metritis, milk yield did not differ between subclinical HYPO and normocalcemic cows within the first 4 mo of lactation (Martinez et al., 2012). Jawor et al. (2012) reported that HYPO cows $(\mathrm{Ca}<1.8 \mathrm{mmol} / \mathrm{L}$ or $<7.2$ $\mathrm{mg} / \mathrm{dL}$ ) had greater DMI prepartum and produced 5.7 $\mathrm{kg} / \mathrm{d}$ more milk compared with non-HYPO cows within the first month of lactation. In the present study, milk yield and components (percent fat and protein) as well as SCC for the first 3 DHIA tests were not different between HYPO and non-HYPO cows. Regardless of the calcium status of postpartum cows, Martinez et al. (2012) found an overall milk yield of $37.5 \mathrm{~kg} / \mathrm{d}$ for the first 4 mo of lactation, while Jawor et al. (2012) reported an overall milk yield of over $40 \mathrm{~kg} / \mathrm{d}$ for the first month of lactation. Lactating cows under the certified organic management described above had an overall milk yield for the first 3 DHIA tests of $31.6 \mathrm{~kg} / \mathrm{d}$, approximately 16 to $21 \%$ less milk compared with amounts reported by Martinez et al. (2012) and Jawor et al. (2012), respectively. In our study, only 4 postpartum cows had total serum calcium concentration $<1.6 \mathrm{mmol} / \mathrm{L}$ and most of the HYPO cows had serum calcium concentration of 1.6 to $2.0 \mathrm{mmol} / \mathrm{L}$. Although HYPO was solely defined using serum calcium concentration $(\leq 2.0$ $\mathrm{mmol} / \mathrm{L}$ ) within $2 \mathrm{~h}$ after calving, recumbency was not observed in cows experiencing HYPO. Perhaps this low prevalence of clinical HYPO or the overall milk production early in lactation could explain, at least in part, the differences observed between studies on milk yield in HYPO and non-HYPO cows.

An interesting finding was that a greater proportion of female heifer calves born from HYPO cows had diarrhea within $10 \mathrm{~d}$ of age compared with those born from non-HYPO cows. Although the intestinal permeability is high within the first $24 \mathrm{~h}$ after birth to facilitate immunoglobulin absorption from colostrum, it also increases the risk for bacterial translocation and susceptibility to infections (Berg, 1995; Godden et al., 2009). A recent study reported that dairy calves experiencing diarrhea between 7 and $14 \mathrm{~d}$ of life had altered intestinal permeability within the first $2 \mathrm{~h}$ of life compared with nondiarrheic calves (Araujo et al., 2015). The first and last colostrum administration (timing, quality, and quantity) was the same for all calves in the study, and they achieved optimum IgG passive transfer (Araujo et al., 2015). Interestingly, Araujo et al. (2015) proposed that the barrier function of intestinal epithelium of calves with diarrhea may have been damaged (increased permeability) prior to the first colostrum intake. Although preweaning body growth rate was not assessed in this study, previous work has shown that neonatal calves experiencing diarrhea and treated with antibiotics had reduced average daily gains of $50 \mathrm{~g} / \mathrm{d}$
(Van Amburgh et al., 2014). Although female calves did not necessarily receive colostrum from their dams, all calves in the present study received the same quantity $(4 \mathrm{~L})$ and quality (colostrometer; >50 IgG mg/ $\mathrm{dL}$ ) of colostrum within $3 \mathrm{~h}$ after birth. Additionally, the proportions of dystocia, stillbirth, and serum total protein were not different between calves born from HYPO and non-HYPO cows. Therefore, these findings highlight the role of prepartum maternal factors on the development of diarrhea in newborn calves.

To make the calf immunocompetent at and after birth, the hypothalamo-pituitary-adrenal (HPA) axis and immune system develop together (Matthews, 2002; Hulbert and Moisá, 2016). Immunocompetence involves several systems, such as barriers (skin and mucosa), surveillance-and-combat (neutrophils, macrophages, and humoral complement factors), control, and documentation (Hulbert and Moisá, 2016). More than half of the fetal growth occurs during the last 2 mo of gestation (Van Saun and Sniffen, 2014), and prenatal stressors within the uterine environment influence the development of a functional HPA (Matthews, 2002). Perhaps cows experiencing HYPO at calving had already been exposed to a stressor (e.g., restricted DMI) during the last 2 mo of gestation as opposed to nonHYPO cows. Therefore, a prepartum stressor is likely transmitted to the fetus, influencing the proper HPA development (Matthews, 2002). Without a functional HPA at birth, newborn calves may be immunocompromised and prone to developing enteric diseases early in life (Hulbert and Moisá, 2016). This dysfunctional HPA may reduce the concentration of circulating fetal glucocorticoids before parturition that are needed after birth for the stimulation of tight junction and mucosal formation in the digestive tract of newborn calves (Liggins, 1994; Hulbert and Moisá, 2016).

The neonate may be programmed maternally (in utero) as described above and postnatally through milk- or colostrum-related factors (Bartol et al., 2008). Colostrum plays a major role in calf health, primarily through passive absorption of IgG (Godden et al., 2009). However, colostrum is also rich in many vitamins, minerals, and molecules such as lactoferrin, relaxin, prolactin, insulin, and IGF-1, among others (Odle et al., 1996; Blum and Hammon, 2000; Kehoe et al., 2007; Bartol et al., 2008). Although IgG concentration was the only colostrum component measured in the present study, colostral vitamins and nutrients in HYPO and non-HYPO cows were not assessed. Because female calves did not necessarily receive colostrum from their dams and concentrations of serum IgG were relatively the same for all calves, a possible hypothesis is that HYPO cows could alter permeability of the intestinal 
epithelium of calves prepartum or yield colostrum of different composition (other components than IgG) compared with non-HYPO cows, compromising neonatal calf health before weaning. Further studies are needed to assess the association between prepartum cow management (i.e., calcium and energy status at calving) and neonatal calf health, accounting for the effect of prepartum management and colostrum components.

\section{CONCLUSIONS}

The overall prevalence of HYPO was $14.6 \%(2.7 \%$ for primiparous and $30.8 \%$ for multiparous cows). Cows experiencing HYPO at calving had greater proportions of metritis and culling within 60 DIM compared with non-HYPO cows; however, milk yield and components as well as the proportion of PAI at first service did not differ between groups. Although the proportion of stillbirth and serum total protein were not different, calves born from HYPO cows had a greater incidence of diarrhea than calves born from non-HYPO cows. Findings from the present study show that HYPO at calving had significant health implications for both dams and calves. When troubleshooting neonatal health problems is undertaken, the health status of the dams should also be assessed.

\section{ACKNOWLEDGMENTS}

The authors thank the collaborating dairy farm and their staff for providing the animals used in the present study and for their assistance during the project. This project was partially supported by the Ohio Dairy Producer Association (Columbus), the National Institute of Health T35 Fellow Scholarship, and The Ohio State University Veterinary Extension.

\section{REFERENCES}

Araujo, G., C. Yunta, M. Terré, A. Mereu, I. Ipharraguerre, and A. Bach. 2015. Intestinal permeability and incidence of diarrhea in newborn calves. J. Dairy Sci. 98:7309-7317.

Bartier, A. L., M. C. Windeyer, and L. Doepel. 2015. Evaluation of on-farm tools for colostrum quality measurement. J. Dairy Sci. 98:1878-1884

Bartol, F. F., A. A. Wiley, and C. A. Bagnell. 2008. Epigenetic programming of porcine endometrial function and the lactocrine hypothesis. Reprod. Domest. Anim. 43:273-279.

Berg, R. D. 1995. Bacterial translocation from the gastrointestinal tract. Trends Microbiol. 3:149-154.

Blum, J. W., and H. Hammon. 2000. Colostrum effects on the gastrointestinal tract, and on nutritional, endocrine and metabolic parameters in neonatal calves. Livest. Prod. Sci. 66:151-159.

Chapinal, N., M. Carson, T. F. Duffield, M. Capel, S. Godden, M. Overton, J. E. Santos, and S. J. LeBlanc. 2011. The association of serum metabolites with clinical disease during the transition period. J. Dairy Sci. 94:4897-4903.

Curtis, C. R., H. N. Erb, C. J. Sniffen, R. D. Smith, P. A. Powers, M. C. Smith, M. E. White, R. B. Hillman, and E. J. Pearson. 1983. Association of parturient hypocalcemia with eight periparturient disorders in Holstein cows. J. Am. Vet. Med. Assoc. 183:559-561.

Dubuc, J., T. F. Duffield, K. E. Leslie, J. S. Walton, and S. J. LeBlanc 2010. Risk factors for postpartum uterine diseases in dairy cows. J. Dairy Sci. 93:5764-5771.

Ferguson, J. D., D. T. Galligan, and N. Thomsen. 1994. Principal descriptors of body condition score in Holstein cows. J. Dairy Sci 77:2695-2703

Godden, S. M., D. M. Haines, K. Konkol, and J. Peterson. 2009. Improving passive transfer of immunoglobulins in calves. II: Interaction between feeding method and volume of colostrum fed. J Dairy Sci. 92:1758-1764.

Goff, J. P. 2008. The monitoring, prevention, and treatment of milk fever and subclinical hypocalcemia in dairy cows. Vet. J. 176:50-57.

Goodell, G. M., J. Campbell, L. Hoejvang-Nielsen, W. Stansen, and P. D. Constable. 2012. An alkalinizing oral rehydration solution containing lecithin-coated citrus fiber is superior to a nonalkalinizing solution in treating 360 calves with naturally acquired diarrhea. J. Dairy Sci. 95:6677-6686.

Hulbert, L. E., and S. J. Moisá. 2016. Stress, immunity, and the management of calves. J. Dairy Sci. 99:3199-3216.

Huzzey, J. M., D. M. Veira, D. M. Weary, and M. A. G. von Keyserlingk. 2007. Prepartum behavior and dry matter intake identify dairy cows at risk for metritis. J. Dairy Sci. 90:3220-3233.

Jawor, P. E., J. M. Huzzey, S. J. LeBlanc, and M. A. von Keyserlingk 2012. Associations of subclinical hypocalcemia at calving with milk yield, and feeding, drinking, and standing behaviors around parturition in Holstein cows. J. Dairy Sci. 95:1240-1248.

Kehoe, S. I., B. M. Jayarao, and A. J. Heinrichs. 2007. A survey of bovine colostrum composition and colostrum management practices on Pennsylvania dairy farms. J. Dairy Sci. 90:4108-4116.

Kimura, K., T. A. Reinhardt, and J. P. Goff. 2006. Parturition and hypocalcaemia blunts calcium signals and immune cells of dairy cattle. J. Dairy Sci. 89:2588-2595.

LeBlanc, S. J., T. F. Duffield, K. E. Leslie, K. G. Bateman, J. TenHag, J. S. Walton, and W. H. Johnson. 2002. The effect of prepartum injection of vitamin E on health of transition dairy cows. J. Dairy Sci. 85:1416-1426.

LeBlanc, S. J., K. E. Leslie, and T. F. Duffield. 2005. Metabolic predictors of displaced abomasum in dairy cattle. J. Dairy Sci 88:159-170.

Liggins, G. C. 1994. The role of cortisol in preparing the fetus for birth. Reprod. Fertil. Dev. 6:141-150.

Martinez, N., C. A. Risco, F. S. Lima, R. S. Bisinotto, L. F. Greco, E. S. Ribeiro, F. Maunsell, K. Galvão, and J. E. P. Santos. 2012 Evaluation of peripartal calcium status, energetic profile, and neutrophil function in dairy cows at low or high risk of developing uterine disease. J. Dairy Sci. 95:7158-7172.

Martinez, N., L. D. P. Sinedino, R. S. Bisinotto, E. S. Ribeiro, G. C. Gomes, F. S. Lima, L. F. Greco, C. A. Risco, K. N. Galvão, D. Taylor-Rodriguez, J. P. Driver, W. W. Thatcher, and J. E. P. Santos. 2014. Effect of induced subclinical hypocalcemia on physiological responses and neutrophil function in dairy cows. J. Dairy Sci. 97:874-887.

Matthews, S. G. 2002. Early programming of the hypothalamo-pituitary-adrenal axis. Trends Endocrinol. Metab. 13:373-380.

NRC. 2001. Nutrient Requirements of Dairy Cattle. 7th rev. ed. National Academies Press, Washington, DC.

Odle, J., R. T. Zijlstra, and S. M. Donovan. 1996. Intestinal effects of milkborne growth factors in neonates of agricultural importance. J. Anim. Sci. 74:2509-2522.

Planski, B., and N. Abrashev. 1987. Dynamic aspects of mineral metabolism in dry cows, puerperants and calves. Vet. Med. Nauki $24: 48-57$.

Reinhardt, T. A., J. D. Lippolis, B. J. McCluskey, J. P. Goff, and R. L. Horst. 2011. Prevalence of subclinical hypocalcemia in dairy herds. Vet. J. 188:122-124. 
Roberts, T., N. Chapinal, S. J. LeBlanc, D. F. Kelton, J. Dubuc, and T. F. Duffield. 2012. Metabolic parameters in transition cows as indicators for early-lactation culling risk. J. Dairy Sci. 95:30573063.

SAS Institute. 2009. SAS/STAT 9.2 User's Guide. 2nd ed. SAS Institute Inc., Cary, NC.

Schuenemann, G. M., S. Bas, E. Gordon, and J. D. Workman. 2013. Dairy calving management: Description and assessment of a training program for dairy personnel. J. Dairy Sci. 96:2671-2680.

Schuenemann, G. M., I. Nieto, S. Bas, K. N. Galvao, and J. Workman. 2011a. Assessment of calving progress and reference times for obstetric intervention during dystocia in Holstein dairy cows. J. Dairy Sci. 94:5494-5501.

Schuenemann, G. M., I. Nieto, S. Bas, K. N. Galvão, and J. Workman. 2011b. II. Dairy calving management: Effect of perineal hygiene scores on metritis. J. Dairy Sci. 94:744.
Seifi, H. A., S. J. LeBlanc, K. E. Leslie, and T. F. Duffield. 2011. Metabolic predictors of post-partum disease and culling risk in dairy cattle. Vet. J. 188:216-220.

USDA. 2008. Dairy 2007, Part II: Changes in the U.S. Dairy Cattle Industry, 1991-2007. USDA-APHIS-VS, CEAH, Fort Collins, CO.

Van Amburgh, M. E., F. Soberon, D. J. Lopez, J. Karszes, and R. W. Everett. 2014. Early life nutrition and management impacts longterm productivity of calves. Pages 35-49 in Florida Dairy Production Conference, Gainesville, FL.

Van Saun, R. J., and C. J. Sniffen. 2014. Transition cow nutrition and feeding management for disease prevention. Vet. Clin. North Am. Food Anim. Pract. 30:689-719. 